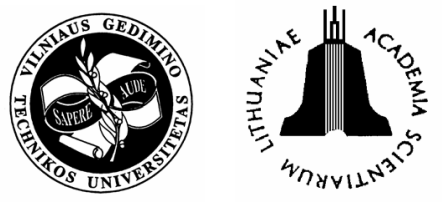

\title{
ASSESSING THE DEGREE OF INDUSTRIALISATION IN CONSTRUCTION - A CASE OF UGANDA
}

\author{
Henry Mwanaki Alinaitwe ${ }^{1}$, Jackson Mwakali $^{2}$ and Bengt Hansson ${ }^{3}$ \\ ${ }^{1}$ Dept of Civil Engineering, Makerere University, P. O. Box 7062, Kampala, Uganda. \\ E-mail: alinaitwe_h@tech.mak.ac.ug \\ ${ }^{2}$ Dept of Civil Engineering, Makerere University, P. O. Box 7062, Kampala, Uganda. \\ E-mail: mwakali@tech.mak.ac.ug \\ ${ }^{3}$ Division of Construction Management, Lund University, P. O. Box 118, Lund, 221 00, Sweden. \\ E-mail: bengt.hansson@bekon.lth.se
}

Received 12 Aug 2005; accepted 12 Jan 2006

\begin{abstract}
Industrialisation is seen as one of the philosophies that can be employed to be able to increase the productivity of the construction industry. There are many forms and classifications of industrialisation and these have to be put in the context while seeking improvement of productivity by industrialisation. A systems approach is used to analyse the players and factors for industrialisation of the construction sector. Case studies were used to study industrialisation in the construction sector in a developing country. Performance metrics are suggested and used to measure the extent of industrialisation in Uganda. It is concluded that the level of industrialisation in Uganda seems to be low. However, there is a need for a wider comparison in order to come up with generic indicators.
\end{abstract}

Keywords: industrialisation, construction, metrics, systems analysis, productivity, developing countries.

\section{Introduction}

\subsection{Definition}

Foster [1] defines industrialisation essentially as an organisational process - continuity of production implying a steady flow of demand; standardisation; integration of the different stages of the whole production process; a high degree of organisation of work; mechanisation to replace human labour wherever possible; research and organised experimentation integrated with production. According to International Council for Research and Innovation in Building and Construction (CIB) TG57, (www.cibworld.nl), industrialisation involves the rationalisation of the whole process of building (which includes the process of design, the forms of construction used and the methods of building adopted), in order to achieve integration of design, supply of materials, fabrication and assembly so that building work is carried out more quickly and with less labour on site and, if possible, at less cost. Industrialisation of construction deals with the rationalisation of the construction process through prefabrication, extensive on-site use of forms, equipment, and advanced labour saving finish technologies (http://tx.technion.ac.il). Richard [2] defines industrialisation as basically the aggregation of a large market to divide into fractions the investment in strategies and technologies capable, in return of simplifying the production and therefore reducing the costs.

\subsection{Why to industrialise construction?}

Increasingly heavy demands for the products of the building industry were made in the years following the end of the Second World War during the reconstruction programmes. Since this War, the world population has more than doubled. Currently, the demand on housing is very high and the number of homeless people has been growing. For example, more than $25 \%$ of the population in Uganda do not have an adequate shelter [3]. There is also a big number of huge construction projects, which are undertaken. While the increase in demand of construction products is happening, there is a growing shortage of skilled manpower. Shortage of manpower is unlikely to diminish to any significant extent [1]. To deliver quality architecture to the vast majority of people, the building industry should move to full industrialisation [2].

The problem of low and decreasing labour productivity is typical of many countries. For example, Teicholz [4] found out that labour productivity in the United States has continued to slowly decline (with a few exceptions) over the past 25-30 years. The important topic addressed in the Emerson report [5], the Latham report [6] and the Egan report [7] is the issue of productivity in the construction industry. Egan has recommended rethinking construction largely through industrialisation just like in other industries. Comparison was drawn largely from the car industry. Strategies like industrialisation would reduce the cost of construction by $30 \%$ when increasing productivity. 
The level of industrialisation in Uganda seems to be low. For example, most workers do not have all necessary tools and equipment to help them in the construction process. Lack of necessary tools and equipment coupled with low skill levels and poor management generally have led to low levels of productivity. Industrialisation of construction is needed to increase the productivity of the industry while at the same time reducing the amount of site labour involved. The aim of this paper is to understand, describe and analyse the industrialisation of construction through indicators.

\section{Classification of industrialisation}

The existing strategies for industrialisation can be divided into on-site industrialisation and off-site industrialisation. Another split in industrialisation strategies is between the product industrialisation and the process industrialisation.

\subsection{On-site and off-site industrialisation}

Off-site industrialisation is based on the assumption that buildings may also be made in factories. Prefabrication is the production of construction components using factory mechanization. It refers to the manufacture and assembly of buildings or parts of buildings ahead of time that would traditionally be constructed in-situ on site and usually takes place at a manufacturing facility remote from the site. The factory setting enhances affordability through a combination of quantity purchasing of materials, mass production, assembly techniques and use of less skilled labour. The ultimate goal is a radical change that will lead to new buildings, fully constructed with prefabricated elements assembled on site, ready for use. In the housing industry some systems are already successful. Prefabrication may take one of these forms: prefabricated components, modular housing, and manufactured housing.

On the other hand, on-site industrialisation refers to the application of advanced tools and technologies on building sites. Some examples are Ground Positioning System (GPS), assembly of big prefabricated units, identification of elements with bar codes, just is time deliveries, self-climbing formwork, self-levelling concrete, robotic finishing etc. (http://tx.technion.ac.il).

\subsection{Product industrialisation and process indus- trialisation}

Product industrialisation focuses on the technological aspect of building. On-site and off-site are both examples of product industrialisation. On the other hand, process industrialisation is concerned with how parties are cooperating, contractually and informally. It deals with Design and Build contracts or with more advanced strategies like Private Finance Initiative (PFI), Design Build Market and Operate (DBMO).

\section{Key factors of industrialisation}

The key factors of industrialisation of any industry and construction in particular include the following.

- Materials

Materials should be available all the time and when they are needed to avoid unnecessary delays. In this the paradigms of Just-In-Time (JIT) and Supply Chain Management are pertinent. The materials should also be in a form that they are ready to fix into the building and not raw materials that have to be processed on site in order to be able to fix them. In this regard, the concepts of prefabrication are relevant.

Industrialisation assumes that most materials are standardised that materials and components can be manufactured in several places but they can fit in the final product without discrimination based on origin. The components should be easily identifiable by bar codes just like other products.

- Methods

The methods employed in industrial construction should allow a continuous flow of inputs and products. Methods are studied for optimising resources. Industrialisation leads to documentation, so the methods and procedures are clearly spelt out such as advanced in the concept of Total Quality Management [8].

- Men

Men should be skilled in whatever they are doing. Industrialisation promotes specialisation so that the people develop expertise in whatever they are doing. Industrialisation assumes that few people are employed and are supported with tools/machines, so that they are not overworked and their health and safety conditions are well cared for.

- Markets

Industrialisation is usually based on the premise that there will be steady markets for the products so that the flow of products does not stop. The products also must be flexible to satisfy the varying requirements of customers. Industrialisation flourishes where the economies of scale are favoured.

- Money

The assumption made here is that the party that has the money takes the risk to finance the product just like in the cases of Private Finance Initiatives (PFI) and its variants of Turnkey, Build, Own, Operate and Transfer (BOOT), Design, Build, Market and Operate (DBMO).

\section{- Machines}

Industrialisation calls for using the modern technologies such as robots to replace the archaic methods that were mainly labour based. Other examples are the use of self-climbing formwork and GPS positioning. Industrialisation assumes that the basic tools are available and there is a development of processes and tools.

- Management

This requires a high degree of organisation of work so as to minimise delays and wastage. Once again, proc- 
ess industrialisation concepts, like JIT, Supply Chain Management, are pertinent.

The above factors not withstanding, there is conservatism in the construction industry. Manual labour has been used in the construction industry for many generations. People are scared of loosing jobs because of being substituted by machines. Failure to adopt technological change is a great barrier to industrialisation in construction. There are many cultural issues in construction. For example, women are not commonly employed on construction sites in many parts of the world while they form the bigger percentage of the population.

\section{Advantages and disadvantages of industrialisation in construction}

\subsection{Advantages}

The advantages of pre-assembly and standardisation include speed of construction, lower cost, reduced need for skilled labour, high technical quality, independence of weather, reduction in manufacturing costs, fewer interface and tolerance problems, shorter construction periods, and more efficient research and development of components $[7,9]$.

Prefabrication of the housing components such as windows, doors, and cabinets, has been a long main stay of the construction industry, keeping the costs down by reducing on-site, high-cost labour. Modular housing involves the prefabrication of sections of housing that are assembled on site, thereby reducing significantly on-site labour costs. The construction industry needs to make a greater use of prefabrication in undertaking projects in order to overcome manpower shortage [10].

Continued development of prefabrication provides a growing range of construction products that may further reduce construction costs. Industrialisation will lead to improved quality of the products. There is a greater precision and consistency in quality. Industrialisation enables production under controlled conditions, often inside a factory or specialised works, hence protecting products from bad weather.

Industrialisation minimises site activity. There is reduction in construction hazards leading to improvement in the workers' site safety and health. Prefabrication can simplify temporary or permanent removal or replacement with minimum disruption. For example, modular plant rooms located on the roof of a building can be removed and replaced in one operation over a weekend shutdown.

Prefabrication optimises the location of the work where it is more efficiently built in this way. Sometimes this is the only option. It allows suppliers and contractors to exploit special skills or specialised equipment. Expensive or specialized components can be kept secure till installation in final position. For projects on remote sites, relocating the work to workshops could mean a better access to the skilled labour.

Industrialisation and particularly prefabrication will lead to a big reduction in the overall duration of a construction project if well-planned in advance. Process industrialisation leads to transfer of risks from the clients to the suppliers and contractors. This in a way encourages innovation since the risk takers will be forced to find ways of creating and implementing change in the construction industry. Industrialisation taking into account mass production will lead to reduced costs, when the quantities of work are beyond the minimum economic order quantities.

\subsection{Disadvantages}

The use of machines to replace manpower reduces on the jobs available for human labour. In some countries where unemployment is high, this can exacerbate the problem. Therefore the increased use of industrialisation might lead to higher levels of unemployment. Care has to be taken to use appropriate levels of industrialisation. For optimum productivity, there has to be an optimal level of industrialisation.

Use of prefabrication in buildings has the following shortcomings: possibility of damage during transportation; normally it requires lifting equipment; monotony of design unless there are variations in the prefabricated units; and over designs to take care of the loading conditions.

The cost of the technologies and equipment is usually high at the beginning. It was found out that large volumes are required in the long run as the production volume must exceed the critical volume and this is not always the case [9].

\section{More literature on industrialisation in housing}

Changes in building production are essential if the world of construction is to be improved. The changes are necessary because the next few decades will see enormous migration into cities. It is forecasted that by 2015 , $55 \%$ of the world population will live in urban areas compared with $45 \%$ in 1995 [11].

Recently there have been calls for the Henry Ford of housing [12]. Attempts at mass production of housing have in the past failed, with the result that the relative cost of housing compared to other goods and services has been raising inexorably [13].

There is a need to industrialise all sectors of the construction industry. However, the largest backlog in construction is in providing housing to the ever-increasing population. Ideally housing would be easier to provide for using industrialisation in construction because most of the spaces and products can be standardised as exemplified by the precast concrete box units [9]. Variations would only cater for special cases. The industry requires radical changes if improvements in quality, productivity and performance are to be achieved [6,7]. Currently the industry is fragmented with many stakeholders who are not well coordinated. Process industrialisation would help improve the situation.

Since the Second World War, the idea of industrialisation has received much attention both in Europe, North America and elsewhere. However, in spite of a great number of attempts, there has been a relative lack of success of industrialised building methods [14]. The share of 
prefabricated components has risen, and there are examples of advanced industrialisation, notably the Japanese house producers [15] and the American metal-building providers [16], but a wider breakthrough for industrialised construction has still not occurred. According to Warzawski, the main problem of prefabrication of today is the lack of a system approach to its deployment on the part of the various parties involved.

Industrialisation is based on quantity, and that is the very nature of industrialisation. The production of a large quantity of units divides that investment into small fractions, thereby reducing the fixed production costs of a single unit down to marginal amounts and getting the product available to a large market [2]. Koskela and Vrijhoef [17] argue that the template of mass manufacturing was based on the powerful principles of economies of scale, division of work, mechanisation and centralised control. However, due to the peculiarities of constructed product, most of the principles could - and can - be utilised to a limited extent in construction. On the one hand, economy of scale was prevented by the bulkiness of buildings, and, on the other hand, by the variety needed. The need for mobility on site was a barrier for mechanisation. Nevertheless, mass production fascinated construction professionals, and already in the 1930s, a house factory with a moving belt was organised in the USA.

As pointed out by Hounshell [18], Fordised massproduced housing never caught on. It was rather the idea of centralised control that took hold in construction.

Gann noted that attempts to optimise components, subassemblies or subprocesses without evaluating the consequences for the system as a whole led to small improvements, or failure [15]. Industrialised construction shows widely different characteristics in comparison to site construction. In industrialised construction, the flow is longer due to multiple production locations, the amount of design required is larger, the error correction cycle is longer, and requirements for dimensional accuracy are higher than in site construction [19]. The total process of industrialised construction tends to become more complex and vulnerable in comparison to site construction. It seems plausible that in design, prefabrication, and site processes of industrialised construction that are managed in the fragmented mode suggested by the transformation theory, the increase of costs due to increased waste has often consumed the theoretical benefits to be gained from industrialisation.

All systems in developing countries must take advantage of the abundant labour market. This approach would decrease unemployment, reduce the shortage of housing, generate industrial development, and reduce the construction cost. However, for the systems approach to be successful, cooperation between the private sector and various governmental agencies is necessary (Koehn and Ganapathiraju [20]).

In order to improve, the industry must design projects for ease of construction making maximum use of standard components and processes [21]. Designs should be fully developed before the manufacture and site construction begins. When prototype equipment is involved, it must be identified in the initial stage of the project. Detailed programmes for research, design, testing and manufacture must be produced and monitored. This has to be available before the work starts on site [6].

Latham recommended the use of Knowledge Based Engineering (KBE) that has already been developed in manufacturing industry both for aeroplanes and cars [6]. It enables product managers and designers to see new ideas either through advanced computer-aided design or 'Virtual Reality'. All aspects of design, manufacture assembly and use of the product can be presented in one entity. Egan found out that the construction industry invests little in research and development (R\&D) and in capital [7]. In house R \& D in UK has fallen by $80 \%$ since 1981 and capital investment is a third of what it was 20 years ago.

The industry is typically seen as dealing with the project process as a series of sequential and largely separate operations undertaken by individual designers, constructors and suppliers who have no stake in the longterm success of the product and no commitment to it. Changing this culture is fundamental to increasing efficiency and quality in construction. It requires integration of the processes and the team around the product. It was observed that $80 \%$ of the inputs into buildings are repeated [7]. The advice offered to construction by leading manufacturing industries is to approach change by first sorting out the culture, then defining and improving processes and finally applying technology as a tool to support these cultural and process improvements.

Richard [2] points out five degrees of industrialisation that can be identified. These are prefabrication, mechanisation, automation, robotics and reproduction. Prefabrication implies building components before and/or elsewhere. Mechanisation comes in whenever machinery is employed to ease the labour work. With automation, the tooling is completely taking over the tasks performed by the labour and with robotics; the tooling has the multiaxis flexibility to perform by itself diversified tasks. Reproduction is the introduction of innovative technology capable of simplifying the multiplication of complex goods. Instead of investing straight into machinery, reproduction is first calling upon research and development for ideas to generate a simplified process. Reproduction implies that priority is given to ideas rather than machinery. It is the introduction of an innovative technology capable of simplifying the production of complex goods, of shortcutting long sequential operations. Construction engineering will be changed by the application of more industrial production, sustainable production, mass individualisation, and intelligent building to improve constructability [11].

\section{Research methodology for industrialisation in construction}

\subsection{Methodology}

Anderson [21] refers to Andersson and Borgbrant [22] where research design by type of research and research processes are outlined. The types of research are 
change oriented, evaluation oriented, theory and model oriented, and experimental oriented. Change oriented research aims at change in a production process, administrative routines and communication systems. It is confined to the organisation and people concerned with the subject of change. Evaluation oriented research requires a clear problem statement and purpose, which settles the research process by choice of target group. It can be addressed to the individuals, organisation or other parties directly concerned with the evaluation. Theory and model oriented research aims at increasing knowledge within a delimited subject. Experimental research aims at analysing and specifying well-defined properties of specific subjects. The research handles delimited problems where a few, controllable parameters can be analysed.

The study of industrialisation in construction is associated with the theory and model oriented approach. According to Kuhn [23], there are three basic types of research approach and these are analytical approach, systems approach and actors approach. The analytical approach reduces the analysis of the sector to the study of demarcated parts of construction and does not primarily include the interaction and relations between the parts. The systems approach comprises of interacting parts and accordingly the parts of the construction sector are described based on the general characteristics of the sector in a holistic view. The actors approach describes the whole by the properties of the parts [24].

This study is based on the systems approach as it corresponds to the fundamental idea of industrialisation of construction. We shall then describe parts of the system by the characteristics of the total.

\subsection{Systems theory}

The systems approach is in a broader sense about understanding the overall driving forces or indicators that affect the system as a whole. It relies on both measurable and non-measurable information, ie quantitative and qualitative data.

Generally, there are two kinds of connections between components, namely causality and finality relations. A causal relationship implies that one event must lead to another event, in either a deterministic way or probabilistic way while a finality relation is determined by the comprehensive situation in which the event occurs and can be described in terms of indicator and effect relations. The systems approach implies identifying finality relations, ie indicator and effect relations, on a comprehensive level compared to the more precise and detailed cause and effect relations of the analytical approach. In the complex, dynamic and interdependent composition of reality according to the systems approach, it would be meaningless, or impossible, to state detailed cause and effect relations [25].

Anderson and Johnson [26] describe five basic principles of the systems approach expressed as the adoption of a comprehensive view, the finding of a balance between short-term and long-term perspectives, the identification of the dynamic, complex and interdependent characteristics of a system, the consideration of measur- able as well as non-measurable factors, the study of a system, in which the observer/ researcher is a part, makes the observer/researcher influencing the system and vice versa, the system influences the observer/researcher.

With the systems approach, the researcher takes a holistic, rather than a reductive, perspective on the problem [27]. The systems approach means studying components that are in inevitable interaction with each other instead of having potential cause-effect relations.

Mechanistic thinking generates knowledge by analytically reducing complex phenomena into their component parts to understand the whole. In contrast, systems theory begins with the premise that the world is composed of systems that cannot be fully understood by being divided into parts. A system is seen as being the sum of the interactions of its parts. Systems theory recognises the common sense notion that when you take a system apart, each part loses the fundamental properties that characterise the system. Thus the systems dilemma states that you cannot understand the nature of a system through a mechanistic analysis. Systems theory is for quest for knowledge of how the system operates as a whole, including its role or function in the wider environment of a more encompassing system.

According to Checkland and Scholes [28], systems can be divided into soft and hard ones. Hard systems are appropriate in well-defined problems while soft systems are appropriate when the problem is vague and ill defined. The 'world' is the system in the 'hard' approach while in the soft system, the world is complex and can be described and understood by the system. Hard systems illustrated in [29] can be used to define the linkages between parties in the construction process. According to Anderson and Johnson [26], soft systems can be used to analyse the links between the different parties in the construction process. It can be concluded that the hard systems examine the relations and between which parties in the process they exist, while the soft systems approach deal with the contents of the relations.

Any given system consists of components and their relationships [26, 27, 29]. In the construction process, these may be the different parties and the relations between them. It may be the different components that form the relationships and how they are interconnected. By taking away any of the components or relations, the system will not work properly [26]. The underlying assumption of the systems approach is that the reality is arranged in such a way that the whole differs from the sum of its parts. This means that not only the different parts of the system must be studied, but also their relations. Every subsystem can be regarded as a separate system of its own [29].

A system may be open or closed [29]. An open system means that its environment can influence it, while a closed system cannot be influenced. The environment comprises factors of importance to the system, but which are beyond the control of the system. The construction process is an open system as it is greatly influenced by its environment, for instance the regulations. If this definition is applied to construction projects, industrialisation is a factor but is beyond the control of project. 
The disadvantage with the systems approach is that every system is unique. There is a problem of generalisation, in the sense that if one system component is replaced, a whole new system is acquired which may give a different output. Senge [30] models systems dynamics by presenting a graphical display of reinforcing and balancing loops and delays. First, systems concepts are identified and key relationships are made explicit. Then the concepts and relationships are organised into causality loops identifying feedback processes.

\subsection{Case study}

A case study is an empirical inquiry that investigates a contemporary phenomenon within its real-life context, especially when the boundaries between phenomenon and context are not clearly evident [31]. In a case study, a phenomenon is investigated within context where variables are numerous and qualitatively different so that no single survey or data collection approach can be appropriately used to collect information about these variables [32].

\subsection{Measure of industrialisation}

Richard [2] points out that five degrees of industrialisation can be identified. These are prefabrication, mechanisation, automation, robotics and reproduction. Reproduction is not necessarily available as a down right option: it is often present together with some of the other degrees of industrialisation [11].

The following indicators can be used to measure the degree of industrialisation at the activity, company and industry level.

- Level of prefabrication - this can be measured by the ratio of value of work done on site to the value of work done off site.

- Extent of use of mechanisation - this includes use of high-tech machines and technologies.

- Degree of automation - the more the system is automated, the more industrialised it is regarded.

- Use of robotics - the more the robots are used, the more industrialised the industry is regarded.

- Reproduction - the more and the ease with which products are reproduced is an indicator of degree of industrialisation.

Further measures that can be used include:

- Degree of standardisation - the more standardised the building components and construction procedures are, the higher the degree of industrialisation.

- Professionalised skilled labour - the skills and training of the craftsmen should also be regarded as indicators of industrialisation.

- Continuity of production. This can be measured by the time taken to accomplish the project as a ratio of the planned time.

- Organised experimentation integrated with production. The indicator of this could be the ratio of the cost of research and development (R\&D) as a percentage of the annual turnover.
- Use of labour saving technologies. This can be measured by cost of labour as a percentage of cost of construction. The higher the value, the less industrialised the industry is regarded.

- $\quad$ Extensive use of forms - the more forms are used to assemble building parts, the more industrialised it is regarded.

- $\quad$ Type of contract used - contracts that integrate the different stages of the whole production process are regarded as encouraging industrialisation while those that are fragmented do not encourage industrialisation.

The following variables are used to evaluate the degree of industrialisation at the industry level: Competitive advantage, logistical support requirements, environmental requirements, local market demand, export market potential, related markets, technology, infrastructure, suppliers, strategic requirements, market considerations, and current capacities (Buys, [33]).

\section{Case studies on industrialisation of construction in Uganda}

Two case studies of leading construction contractors were made. The choice was made after consulting UNABCEC (Uganda National Association of Building and Civil Engineering Contractors), the association that unites registered contractors. The advice from UNABCEC was that the two companies are the leaders of prefabrication/industrialisation in Uganda.

\subsection{Case I}

In the first case, the contractor deals in fabrication of steel structures mainly industrial buildings made of steel portal frames and elevated steel water tanks. They are the leading contractors in their area of specialisation. Advance payment of $40 \%$ is usually made by the client at the beginning and the rest paid upon completion and installation. The major clients mainly include individuals, firms and government departments who approach them directly. These clients do not generate big quantities of work at a go and only a few projects are handled at a go. The annual turnover in 2004 was about Ushs 3 billion (US \$ 1,7 million).

Most of the components are prefabricated in the contractor's yard and transported to the sites where they are installed. The cost of prefabrication accounts for $50 \%$ of the construction costs. They have a range of machines including cutters, benders, rollers, shearers, and welding machines and therefore easily fabricate the components. The value of the machinery is about Ushs 500 million (US \$ 300,000) which is about $16 \%$ of annual turnover. However, the processes are not automated meaning that people still have to control and operate the machines and load them. The components are moved from one machine to another. The steel frames are heavy, hence the need to use cranes to handle most of the time although men are also used to handle the lighter sections. They have low bed trucks for transporting the components to sites and a crane for lifting purposes among other major plant. There 
is no use of robots at all. About $30 \%$ of the components manufactured are standard. The rest are made on orders made by customers.

Most of the workers are not skilled and information provided was that their labour has a high turnover. The cost of labour as a percentage of construction activity is in the region of $40 \%$. They have a full time labour force of 44 men, five, ie $11 \%$, of whom are expatriates and skilled. Almost all the 39 local workers are semi-skilled, having attained their training on the job.

Consultants carry out the majority of the designs and hence there is minimum reproduction of the components from one project to another. Most of the contracts are of traditional type. In the majority of cases, construction is not integrated with design. The planned time is on average exceeded by $20 \%$ of the planned time because of delays due to delayed payment from the clients.

The company saves $50 \%$ of what the cost of labour would have been by prefabricating the components. The company spends about $0,1 \%$ of its annual turnover on Research and Development. There is no experimentation coupled with production, as it is regarded as an unnecessary cost.

\subsection{Case II}

In the second case, the contractor deals in building construction and roadwork. Their annual turnover in 2004 was about Ushs 22 million (US \$ 12 million). They have a plant that manufactures various building components including concrete blocks, concrete pavers, bricks, roofing tiles, metal fabrication, and carpentry products. They also have a plant that makes concrete mixes and asphalt premix for road works. The products are for use on the projects undertaken by the contractor and the surplus for sale to other contractors. In addition, the contractor fabricates the other building components within the yard, which are later transported to the sites for installation. The value of prefabricated components is about $60 \%$ of the company sales. The plant for manufacturing building components, and asphalt premix and concrete mixes are automated. The value of their plant is about Ushs 10 billion (US \$ 5,5 million). This is about $45 \%$ of their gross turnover. However, work at the sites is not automated. This means that the plant is not in production in many cases because of lack of continuous flow of materials.

There are no robots used at all on their sites. However, $70 \%$ of the components that they make are standard and reproducible. The market is mainly comprised of government departments and most jobs are won through the public tender process. Most of the work is financed by the contractor and payment made by the client upon certification. The traditional form of contract is mostly used. The planned time is on average exceeded by $20 \%$ of the planned time because of delays due to poor contract management. The company has a workforce of 203 workers. 13 of them are highly skilled expatriates. There are 190 locally recruited workers and 30 of them are skilled while the rest are semiskilled and unskilled. That implies that the skilled workers comprise $22 \%$ of the workforce. Prefabricated components are used once in a while. The prefabrication is at the level of manufacturing building components including blocks, tiles, windows and other elements. The company owns a fleet of concrete mixers and other plant. However, observations made during the 9 days of this study were that the trucks were parked most of the time during the study.

The designs for buildings and other civil engineering structures are carried out by consultants and thus there is minimum reproduction of the projects in total from one project to another. Most of the construction contracts are of traditional type where design is separate from the construction. The company saves $40 \%$ of what would have been the cost by prefabricating the components. However, they still spend about $30 \%$ of the gross project costs on labour. Information provided was that the company spends less than $0,5 \%$ of their turnover of UShs 22 billion (US $\$ 12$ million) on R\&D. This is directed towards development of materials.

\section{Discussion}

From the case studies, the level of prefabrication is in the region of $50-60 \%$ of the construction cost. However, the prefabrication is mainly for components rather than modules. The value of machinery in the two cases was $16 \%$ and $45 \%$ respectively of the annual turnover of the company. When this is compared with some other industries in manufacturing where value of machinery is $300 \%$ of the annual turnover, it indicates that investment in mechanisation in construction in Uganda is still very low. The first case study indicates that there is no automation and robots used at all in Uganda. In the second case study, the there is some automation at the plant but no robots are used at all. This shows that the industry has a long way to go in the use of automation and robots.

In the first case study, $30 \%$ of the components manufactured are standard and reproducible while in the second case $70 \%$ of the components are. However, a lot of work still goes on outside on the sites. Professional skilled labour in the two case studies of $11 \%$ and $22 \%$ of the workforce is low in comparison with some manufacturing companies like motor vehicle industries in developed countries where all workforce is professional and skilled. The cases demonstrate that there is usually about $20 \%$ time overrun. Highly industrialised organisations do not allow time overruns. The trend in these days is for Just-In-Time deliveries so that no body suffers the consequences of delays.

The cases indicate that only $0,1 \%$ and $0,5 \%$ of the annual turnover is spent on R\&D. This level of spending is low compared with the average of $3 \%$ of annual turnover spent on R\&D in other industries. The cost of labour as a percentage of project costs of $30-40 \%$ is still in the range for normal construction spending on labour. In manufacturing industries, labour costs about $10-15 \%$ of the production cost. The high labour costs indicate that that the level of industrialisation is still low in Uganda. Both cases have demonstrated that it is the traditional form of procurement that they use to get contracts and this is used for most contracts in Uganda. This form of procurement does not integrate the different stages of the 
whole production process and does not encourage industrialisation.

\section{Conclusions}

For industrialisation to be of great benefit to the construction industry, it is necessary to have big quantities of work to allow for mechanisation, automation and reproduction to be employed effectively. Small fragmented pieces of work will not encourage industrialisation to take advantage of economies of scale. There seem to be signs of industrialisation though the different processes are not integrated. The general conclusion is that construction industry in Uganda seems to have a low level of industrialisation as by the indicators from the cases. This research has used two case studies. It is recommended that further research be carried on a wider extent and in comparison with other industries in order to confirm the validity and reliability of indicators and in order to develop generic indicators usable across different industries. Research is also needed on how industrialisation affects labour productivity.

\section{Acknowledgements}

The authors acknowledge the support given by Sida/SAREC for the research work.

\section{References}

1. Foster, J. S. Structure and fabric. Part I. Longman. $5^{\text {th }}$ ed., 2000. 10 p.

2. Richard, R. Industrialized building systems: reproduction before automation and robotics. Automation in Construction, 14(4), 2005, p. 442-451.

3. Uganda Bureau of Statistics. Statistical abstract. Government of Uganda, 2005. 56 p.

4. Teicholz, P.; Goodrum, P. M. and Haas, C. T. U. S. Construction labour productivity trends, 1970-1998. Journal of Construction Engineering and Management, 127(5), Sept/Oct 2001, p. 427-439.

5. Emerson, H. Survey of the problems before the construction industries. HMSO, 1962. $14 \mathrm{p}$.

6. Latham, M. Constructing the team. HMSO, London, 1994. $6 \mathrm{p}$.

7. Egan, J. Sir. Rethinking construction. Construction Task Force report, Dept of the Environment, Transport and the Regions. HMSO, London, 1998. 26 p.

8. Hoyle, D. ISO 9000, Quality Systems Handbook, Elsevier Butterworth-Heinemann, 2001. 130 p.

9. Hansson, B. Precast concrete box units - a case study. In: The Organization and Management of Construction: Shaping Theory and Practice (Vol II), E\&F Spon, 1996. 4 p.

10. New Strait Times. Use prefabrication, building sector urged. In: Quoting the Singapore deputy minister of works at an International Construction Conference, $9^{\text {th }}$ Nov 2003. $3 \mathrm{p}$.

11. Maas, G. and van Gassel, F. The influence of automation and robotics on the performance of construction. Automation in Construction, 14(4), 2005, p. 435-441.
12. Miles, J. Where is the Henry Ford of future housing systems? Royal Academy of Engineering, London, 1996. 2 p.

13. Winch, G. Zephyrs of creative destruction: understanding the management of innovation in construction. Building Research and Information, 26(4), 1998, p. 268-279.

14. Warzawski, A. Industrialisation and robotics in building: a managerial approach. Haper and Row, New York, 1990. $38 \mathrm{p}$.

15. Gann, D. Building innovation: complex constructs in a changing world. Thomas Telford, London, 2000. 26 p.

16. Ellifritt, D. and LaBoude, R. Building systems. Thin Walled Structures, 16(4), 1993, p. 263-74.

17. Koskela, L. and Vrijhoef, R. Is current theory of construction a hindrance to innovation? Building Research and Information, 29(3), 2001, p. 197-207.

18. Hounshell, D. A. From the American system to mass production 1800 - 1932: the Development of manufacturing technology in the United States. John Hopkins University Press, Baltimore, 1984. 303 p.

19. Koskela, L. An exploration towards production theory and its application to construction. VVT Publications 408, VVT, Espoo, 2000. 42 p.

20. Koehn, E. and Ganapathiraju, V. R. Productivity of construction in developing areas: India. In: Transactions of AACE International. PRD31, 1996, p. 3.1-3.4.

21. Andersson, N. A Mesoeconomic analysis of the construction sector. PhD thesis, University of Lund, Lund, Sweden, 2003. $25 \mathrm{p}$.

22. Andersson, N. and Borgbrant, J. Building science - processes and scientific basis (Byggforskning - processor och vetenskaplighet). Division of Construction Management, Lund University, Lund, Sweden, 1998. 24 p. (in Swedish).

23. Kuhn, T. The structure of scientific revolutions. University of Chicago Press, Chicago, 1990. 18 p.

24. Bjerke, B. Studies in the economics and organization of action. Some comments on methodology in management research. Dept of business administration, University of Lund, No 8, 1981. 14 p.

25. Naslund, D. Towards bridging the gap between strategy and operations - a process based framework. Lund Institute of Technology, 1999. $22 \mathrm{p}$.

26. Anderson, V. and Johnson, L. Systems thinking basics from concepts to casual loops. Waltham, Pegasus Communications Inc., 1997. 3 p.

27. Checkland, P. Systems thinking, Systems practice. Chichester, John Wiley \& Sons, 1999. 5 p.

28. Checkland, P. and Scholes, J. Soft systems methodology in Action. Chichester, John Wiley and Sons, 1999. 5 p.

29. Arbnor, I. and Bjerke, B. Methodology for creating business knowledge. $2^{\text {nd }}$ edition, London, Sage publications, 1997. 109 p.

30. Senge, P. M. The fifth discipline: the art and practice of the learning organization. New York: Doubleday, 1990. 26 p.

31. Yin, R. K. Case study research - design and methods. $3^{\text {rd }}$ ed. Sage, Thousand Oaks, California, 1994. 11 p.

32. Fellows, R. and Liu, A. Research methods for construction. $2^{\text {nd }}$ edition, Blackwell, 2002. $21 \mathrm{p}$.

33. Buys, A. J. Industrialisation guidelines methodology. In: Proc. of $6^{\text {th }}$ Africon Conference in Africa IEEE Africon, 2-4 Oct 2002, Vol 1, p. 447-452. 


\section{UGANDOS STATYBOS INDUSTRIALIZACIJOS LAIPSNIO IVERTINIMAS}

\section{H. M. Alinaitwe, J. Mwakali and B. Hansson}

\section{Santrauka}

Industrializacija yra reiškinys, kuris gali padèti didinti statybos pramonès našumą. Produktyvumui gerinti gali būti pritaikyta daug industrializacijos formų. Statybos sektoriaus industrializavimo dalyviams ir veiksniams analizuoti naudojamas sisteminis požiūris. Konkrečiais pavyzdžiais apibūdinama besivystančios šalies statybos sektoriaus industrializacija. Pasiūlyta ir panaudota Ugandos statybos industrializacijos masto matavimo sistema. Daroma išvada, jog Ugandos industrializacijos lygis yra per menkas. Vis dèlto, norint apibendrinti, reikia išsamesnių tyrimų.

Reikšminiai žodžiai: industrializacija, matavimo sistema, statyba, sisteminè analizė, našumas, besivystančios šalys.

Henry Mwanaki ALINAITWE. PhD student at Lund University and Makerere University on a sandwich programme. His research is on productivity and performance improvement in the construction industry. Member of the Uganda Institution of Professional Engineers. MSc in Construction Management from Loughborough University in the UK and Master in Civil Engineering from the University of Sydney, Australia.

Jackson A. MWAKALI. Head of Dept of Civil Engineering at Makerere University in Uganda. Associate Professor of Civil Engineering, main areas of interest are structures, facilities maintenance, construction techniques and management. Practicing engineer and a member of the Uganda Institution of Professional Engineers. Published several papers in academic journals, conference proceedings and authored textbooks.

Bengt HANSSON. Head of the Construction Management Division at Lund University in Sweden. Professor of Construction Management. Main areas of interest are industrialisation, modularisation, innovation, construction techniques, knowledge management, and performance in the construction industry. Published several papers in conference proceedings, academic journals and authored textbooks. 